THE CHALLENGES OF TEACHING EFL FOR ADULT

LEARNERS: ONLINE LEARNING

DURING THE COVID-19 PANDEMIC

\section{Mugni Assapari}

English Language Education Study Program, Universitas Islam Negeri Mataram Arymugni2021@uinmataram.ac.id
Challenges,

Online

learning,

EFL, Adult

learner

\begin{abstract}
This study was conducted to determine the challenges of teaching EFL for adult learners online learning in UIN Mataram during the covid-19 pandemic. This study used a qualitative method. Data collection instruments are questionnaires and interviews. The findings of this study show that there are challenges for lecturers in teaching EFL for adult learners. In conclusion, this paper has shown so many responses about the challenges experienced by the lecturer, and students while studying online, such as; the positive and negative impact of online learning.
\end{abstract}

Keywords: challenges, EFL, adult learner, online learning

\title{
INTRODUCTION
}

Policy on the implementation of online education conducted by schools and also universities in Indonesia are responding to the Covid-19 pandemic that has hit almost the whole world. The Ministry of Education and Culture of the Republic of Indonesia encourages the implementation of the learning process online. This is by the Circular Letter of the Minister of Education of the Republic of Indonesia number 3 of 2020 on the Prevention of Coronavirus Disease (COVID-19) in the Education Unit, and the Letter of the Secretary-General of the Ministry of Education number 35492/A. A5/HK/2020 dated 12 March 2020 concerning Prevention of Corona Spread Virus Disease (Covid-19). In addition to following the circulars and appeals of each Local Government domicile of Higher Education.

In Indonesia, online learning presents challenges and possibilities for adult learners in college. Like various sectors of society, Indonesia's education system is also uneven, especially because of the covid-19 pandemic. If colleges can stream learning

SPECTRAL Jurnal Ilmiah STBA Vol.7 No.1 Januari 2021 ISSN 0216-3381 online, many students will not have the ability to obtain entry rights to them on an ongoing 
Challenges, Online learning, EFL, Adult learner

012

basis because they do not have a laptop, the fact the cost is too high, internet access is insufficient and internet quota Insufficient. The need now is to replace it with online mastering. This reminds researchers that even though we live in the same country, we now do not share the same resources. Online learning is an open and spread learning system using pedagogy tools, made possible through the internet and network-based technologies to facilitate the formation of learning and knowledge processes through meaningful action and interaction (Dabbagh, 2005). As stated by Inchiparamban \& Pingle (2016) that online learning makes it possible for learners to take up a course without attending an educational institution. Learners get the benefit of taking up a course from their home or from any place they are comfortable with.

Regarding the implementation at UIN Mataram of online classes, the use of technology in supporting online learning depends on three pedagogical factors. The pedagogical approach which is the first factor includes student-centered learning, the role of the teacher as a facilitator, and the integration of knowledge Carrillo \& Flores (2020: 2 ). The main objective of this study was to determine the challenges faced for adult learners in learning English during the Covid-19 pandemic. Even though, students can develop English language skills during difficult times with online learning. Based on observations, It was seen at the beginning of the meeting, WFH's online learning policy made students have to do activities that could still be done at home. This makes many students hone their creativity in English skills during online lectures. Students have many ideas and ways to fill their spare time. Proving that the WFH policy can have a positive impact or change for adult students in learning English, among others; 1) students become more diligent in reading English literature, English journals, or other references that support learning; 2) students can learn and hone soft skills such as making direct interaction communicating English with lecturers who teach English courses and trade online; 3) foster the courage to speak directly; 4) create independence, express ideas, to answer questions in group discussions. Sepulveda-Escobar, P., \& Morrison, A. (2020) suggests that there are several challenging factors in teaching EFL online, such as the lack of direct lecturers 'interaction with students and sudden changes in settings are among those that most strongly influence the participants' learning process. Regardless of the challenges presented, the student-teacher suggested that this unique experience would contribute positively, at least to a specified extent. 
Related to the implementation of online classes, (Carrillo, C., \& Flores, 2020), explained the use of technology in supporting online learning depends on three factors of pedagogy. The first pedagogical factor includes student-centered learning, the role of teachers as facilitators, and the integration of knowledge. The second factor is the design of learning that includes the flexibility of learning, learning that suits the individual needs of each student, according to the context, social, learning process, and the use of Challenges,

Online learning, EFL, Adult learner appropriate tools and technologies. The third factor is facilitation which includes clear expectations, appropriate questions, understanding and sensitivity to cultural issues, timely feedback; constructively; and detail, as well as the high attitude and commitment of the students. The above exposure can be seen in the preliminary study titled "is the online learning good amid the Covid-19 Pandemic? The case of EFL learners" by (Allo, 2020). The purpose of this study was to investigate learners' perceptions of EFL learning online during the COVID-19 pandemic. This research applies to the qualitative method.

The online learning system (in a network) is a learning system without face-toface learning between teachers and students but is done online using the internet network. Lecturers must ensure that teaching and learning activities continue, even though students are at home. The solution, lecturers are required to be able to design learning media as an innovation by utilizing online media. This is by the Minister of Education and Culture of the Republic of Indonesia regarding Circular Number 4 of 2020 concerning Implementation of Education Policies in the Emergency of the Spread of Corona Virus Disease (COVID-19). The learning system is implemented through a personal computer (PC) or laptop connected to an internet network connection. Lecturers can learn together at the same time using groups on social media such as WhatsApp (WA), telegram, Instagram, zoom applications, or other media as learning media. Thus, lecturers can ensure students take part in learning at the same time, even though they are in different places.

All sectors are feeling the impact of the corona. One of them is the world of education. Judging from the surrounding events that are happening, both lecturers and students who do not have cellphones to support online learning activities feel confused. Some students who do not have cellphones are learning in groups, so they do learning activities together. Starting to learn through video calls connected with the lecturer concerned, being asked questions one by one, and taking attendance via Voice Notes 
Challenges,

\section{Online}

learning, EFL, Adult learner

available on WhatsApp. The materials are also given in the form of a video which is less than 2 minutes long. The problems that occur are not only in the learning media system but the availability of quotas that require quite high costs for students and lecturers to facilitate online learning needs. It is clear, the challenge of lecturers as teachers are to find the easiest solution faced by students to remain active in participating in EFL learning as a foreign language in higher education.

Online learning cannot be separated from the internet network. An Internet network connection is one of the obstacles faced by students whose living quarters find it difficult to access the internet, especially since these students live in rural, remote, and disadvantaged areas. Things become a special concern to find a solution. Even if someone uses a cellular network, sometimes the network is unstable, because the geographical location is still far from the range of cellular signals. This is also a problem that often occurs in students who take online learning so that the implementation is not optimal. It should be realized that the unpreparedness of educators and students for online learning is also a problem. The transfer of conventional learning systems to online systems was very sudden, without proper preparation. But all of this must be carried out so that the learning process can run smoothly and students actively follow even in the conditions of the Covid-19 pandemic.

In line with these challenges, the main challenges in online learning during a pandemic. First, lecturers have very limited time in preparing and/or adapting offline learning material to online. Second, the lack of or limited opportunities for teachers and students to interact directly and freely during online learning results in disruption of the learning process. Third, the use of an effective pedagogical approach requires more effort in motivating and activating students in online learning (Huang et al, 2020: 2). The challenges of online learning do appear to be visible before us, not just one or two schools but comprehensive in several regions in Indonesia. The very important components of the online learning process need to be improved and improved. First and foremost is a stable internet network, an application with a user-friendly platform, and online socialization that is efficient, effective, continuous, and integrative to all education stakeholders.

The solution to this problem is that the government has made efforts for teaching and learning quotas that have been distributed free of charge, however, it must provide a policy by opening free online application services in collaboration with internet providers 
and applications to help this online learning process. The government must also prepare an online learning curriculum and syllabus and disseminating information about the procedures for implementing online learning, about their roles and duties. To make it easier and online learning can run smoothly as expected. Thus, online learning is an effective solution for learning at home to break the chain of Covid-19 spread, physical distancing is also a consideration for choosing this learning. Good cooperation between lecturers, students, parents, and universities is a determining factor in making online learning more effective.

\section{METHODS}

\section{Research design}

This research uses a qualitative approach, a type of case study which has the main objective of obtaining in-depth descriptive data, case study research is a research design that is comprehensive, intense, detailed, and in-depth and is more directed as an effort to analyze problems or problems a contemporary phenomenon (Herdiansyah, 2015). Thus, the main objective of this study is to identify and describe the challenges in learning English online faced by adult learners who are just starting with online learning methods. Challenges are identified, analyzed, and described in depth.

\section{Data Collection}

The data was obtained through observations on the English learning process that took place in the period September-December 2020 through the WhatsApp Group of MD A. UIN Mataram Faculty of Da'wah and Communication-Indonesia. Meanwhile, in interviews, researchers conducted interviews with lecturers that covered the challenges faced by lecturers teaching EFL during online lectures. Interviews were also conducted with students to find out the challenges of learning online and the impact of their application on their English skills.

\section{Data analysis}

From the amount of data obtained, then the researchers interpret all the data obtained, including a summary of all findings, comparing the findings with the theory, 
Challenges,

Online

learning,

EFL, Adult

learner

draw conclusions, and propose limits and expectations of further research (Creswell \& Creswell, 2018).

\section{FINDINGS AND DISCUSSION}

\section{Findings}

The implementation of physical distancing policy which then becomes the basis

016 for the implementation of online lectures, by utilizing information technology that applies suddenly, makes lecturers and students because they are not ready. Some lecturers were surprised because they had to change the learning system that initially learned face-toface now all learning is done online. In detail, the findings obtained in this study are described as follows. Based on observations, documentation, and interviews, lecturers and students have challenges about class and technical management during online lectures. Challenges faced by lecturers, and students. In detail, the findings obtained in this study are described in the table as follows. Based on questionnaire data obtained information about online lectures during the Covid-19 pandemic.

Table 1. The Challenges of lecturers In Teaching EFL

\begin{tabular}{|c|c|c|}
\hline No & The Interview Section & Aspects of the challenges \\
\hline 1 & $\begin{array}{l}\text { What are the challenges that } \\
\text { you face for teaching online } \\
\text { English subject in UIN } \\
\text { Maatarm Da'wah Mangement } \\
\text { Program? }\end{array}$ & $\begin{array}{l}\text { The first is students are difficult to access } \\
\text { the internet, so the students are difficult } \\
\text { to get the materials, understanding } \\
\text { materials given by the lecturer, and } \\
\text { difficult to send the assignment to the } \\
\text { lecturer. }\end{array}$ \\
\hline 2 & $\begin{array}{l}\text { Is that all your students difficult } \\
\text { to access the internet? }\end{array}$ & No, it is just several students \\
\hline 3 & $\begin{array}{l}\text { What kind of challenges in } \\
\text { teaching online English } \\
\text { subjects in UIN Mataram? }\end{array}$ & $\begin{array}{l}\text { Several students don't have a } \\
\text { smartphone, while the students that have } \\
\text { it are difficult to access the signal and the } \\
\text { internet data packages. }\end{array}$ \\
\hline 4 & $\begin{array}{l}\text { Is it hard to know the capability } \\
\text { of your students to understand } \\
\text { your material? }\end{array}$ & $\begin{array}{l}\text { Of course, yes. The lecturer does not } \\
\text { much know the students' understanding } \\
\text { of the materials that I have given to them } \\
\text { since they respond are not directly as } \\
\text { good as in online learning. }\end{array}$ \\
\hline 5 & $\begin{array}{l}\text { What's your solution to the } \\
\text { challenges that you have to deal } \\
\text { with? }\end{array}$ & $\begin{array}{l}\text { My solutions are giving additional time } \\
\text { to the students to send their assignment. } \\
\text { Besides, if the students cannot use the } \\
\text { handphone or access the internet, the } \\
\text { students are allowed to send their }\end{array}$ \\
\hline
\end{tabular}


Challenges,

\begin{tabular}{|l|l|}
\hline & $\begin{array}{l}\text { assignments to my house. The teacher } \\
\text { also should be able to find interesting } \\
\text { materials for the students are enjoy and } \\
\text { not boring while learning the materials } \\
\text { and do the assignment. }\end{array}$ \\
\hline
\end{tabular}

Online

learning,

EFL, Adult

learner

Based on data taken from interviews and online questionnaires, the challenges faced by lecturers, namely, some students face limited internet access because the signal area is not well covered. Then, it is also found that some students do not have smartphones, more detailed information such as lecturers prefer to teach offline classes. The lecturer cannot deliver the material directly and do not the students understand the material or do assignments. Students are not active in responding to material provided by lecturers, especially male students and tend to be lazy when learning online. According to observations and interviews with lecturers, clear in table 01, related to the challenges faced by lecturers and universities in Indonesia. Digital transformation in the education sector in Indonesia is not a new discourse that we encounter today, supporting regulations and concrete efforts to implement digital transformation in the college environment. Achieving significant progress on the digital transformation of Indonesian education, Covid-19 or Corona virus has had a tremendous impact in this aspect (Suteki, 2020).

Judging from various aspects Covid-19 is a disaster that negatively affects almost all sectors of human life. Especially efforts to prevent the spread of Covid-19 through Large-Scale Social Restrictions (PSBB) or Lockdown with various appeals at homework from home, Learn from Home, Stay Home, and others. But it is undeniable that the disaster through the Covid-19 pandemic also brought a variety of positive impacts, such as better natural conditions, the ozone layer that was once very thin and the weather feels claustrophobic now the ozone layer becomes stable and orderly, and in the field of education turned out to be the trigger for the acceleration of the digital transformation process of Indonesian education. All universities and schools in Indonesia stopped teaching and learning activities face-to-face including UIN Mataram. However, the teaching and learning process should not stop, nowadays all must run online learning. Inevitably, cannot feel. The result is currently dominant lecturers, teachers, students, and students began to be proficient using various devices and supporting media to learn online. Although it may face various obstacles and various limitations. However, this is 
Challenges,

Online

learning,

EFL, Adult

learner

an advancement that deserves to be grateful for and get used to utilizing technology in the learning process.

Post-Covid-19 later, new normal education that has been started should be continued and modified to meet the concept of blended learning, which is an educational concept that combines the method of face-to-face lectures in the classroom with onlinelearning, related to online-learning in universities, if the measure is "doable", then it is undeniable that all campuses can do it. Both teaching and learners are encouraged to understand at least the use of digital technology. On the other hand, students are also forced to explore information technology and channel their creativity through innovations in the tasks given.

Several information technology platforms have the opportunity to be utilized in supporting online learning activities and at the same time have the opportunity to force lecturers to be literate in information technology. Some of them are as follows: Google sites, e-learning, Zoom meeting, WhatsApp group, and Google Classroom.

a. Google sites are one of the websites media that can be utilized in the learning process.

Google Sites is a website used for group or personal purposes. Google Sites is the easiest way to create information that can be accessed by people who need a quick, and people can work together on the site to add attached file files as well as information from other Google applications such as google docs, sheets, awesome table and so on. The features offered by google sites can support learning (Arief, 2017). The use of google sites can support the effectiveness of distance learning. However, how to make the use of google sites optimal? Therefore, this article will discuss how to make the use of Google sites to be optimal in distance learning.

b. Online learning or e-learning is learning that is done without face-to-face or learning using internet media, a learning process that utilizes information and communication technology (ICT) systematically by integrating all components of cross-space and time learning. E-learning is a learning system that is used as a means of teaching and learning that is carried out without having to face-to-face with the educator and the student (Setiawan, 2020).

c. Zoom is a free HD meeting app with videos and screen sharing for up to 100 people. Zoom is a communication application using video. The application can be used in a variety of mobile devices, desktops, phones, and space systems. 
d. WhatsApp is one of the most popular communication media used today, WhatsApp Challenges, is one of the applications used to conduct conversations using text, voice, and video. WhatsApp to stay in touch with family friends, anytime and anywhere. WhatsApp is free and offers a simple, secure, reliable messaging and calling experience available on phones around the world.

e. Google Classroom is a mixed learning foyer for educational scopes that makes it easier for teachers to create, share and classify each paperless assignment.

Google classroom is an application created by Google that aims to help lecturers and students if they are unable to, organize classes and communicate with students without having to be tied to the schedule of lectures in the classroom. In addition, lecturers can give assignments and directly provide value to students. Delivery of learning with e-learning is learning by utilizing internet technology to improve the learning environment with rich content with a wide scope. E-learning is the utilization of learning media using the internet, to deliver a series of solutions that can improve knowledge and skills. Each learning method must contain the formulation of organizing lesson materials, delivery strategies, and managing activities by paying attention to learning objectives, learning barriers, characteristics of learners, to obtain effectiveness, efficiency, and learning appeal (Miarso, 2004).

It can be concluded that the above exposure from some digital mode platforms mentioned above, WhatsApp is the most familiar among students and lecturers of UIN Mataram, because, before the Covid-19 pandemic, students and lecturers have also intensively communicated and interacted with learning through WhatsApp groups. There is no denying this, where the process aims to avoid the boredom of students in learning and absorb information related to teaching materials, in addition, to avoid monotonous patterns carried out by a large number of lecturers.

Table 2. The Student Challenges Online Learning

\begin{tabular}{|c|l|}
\hline No & \multicolumn{1}{|c|}{ Students challenges } \\
\hline 1 & $\begin{array}{l}\text { students are getting proficient in using various devices and supporting media } \\
\text { to learn online }\end{array}$ \\
\hline 2 & Can access all materials \\
\hline 3 & Make it easy at all times to see the material presented up to date \\
\hline 4 & Obtains plus information's \\
\hline 5 & Before Covid-19, there was never an online learning \\
\hline
\end{tabular}


Challenges,

Online

learning,

EFL, Adult

learner

\begin{tabular}{|c|l|}
\hline 6 & $\begin{array}{l}\text { Only equipped with mobile phone facilities, which have different features of } \\
\text { fun from one student to another }\end{array}$ \\
\hline 7 & Lack of, and limitations of laptop use \\
\hline 8 & Still constrained internet signal and quota. \\
\hline
\end{tabular}

Based on the table above data taken from the interview and online questionnaire,

020 students state that they do not have laptop facilities and students in online lectures use mobile phones as a medium of online lectures. This data shows that there are still many students who have not been able to attend online lectures to the maximum. Based on the factor of time affordability, and different places and far from internet signals.

The paradigm shifts of conventional learning to online, although not difficult, but takes a long time. Because it is related to the paradigm change in academic culture. As the results of the survey of students in the field in the description, there are still many shortcomings that must be addressed and equipped with readiness in learning English online. Based on the survey data above, shows that students are not ready to carry out this online learning, because it concerns academic culture, which includes values, attitudes, knowledge, and skills, as well as the readiness of facilities and infrastructure related to information literacy among students.

\section{DISCUSSION}

\section{Teaching EFL Online Learning}

Concerning the implementation of online learning, students who are claimed to have received challenges from online-learning. Data shows that online-learning offers flexibility, provides up-to-date information, provided rich, unlimited resources, encourages students to read, helps fewer active students become more active, and is faster and simpler. It is easy and makes students more independent in learning, asking, and answering online, through zoom meetings and short messages what app application. According to Rosenberg, online-learning is a form of distance learning, but not all distance learning can be categorized as e-learning. Specifically refers to the use of Internet technology to convey and improve knowledge and skills based on 3 criteria, namely: (1) online-learning is a network capable of making changes, receiving, distributing, and sharing instructions or information quickly; (2) delivered to learners through computers using standard Internet technology; (3) focus on a broad view of a learning solution that is outside the traditional paradigm (Rosenberg, 2001) 
Lecturer challenges are also clearly and clearly visible with the availability of Challenges,

Online

internet facilities by providing teaching materials that are delivered to students can learning, EFL, Adult facilitate with all series of learning, even though distance learning from home to home, learning from the house, has been the path taken by each lecturer in applying and ingesting learner English teaching materials. Another challenges for lecturers and students is with the availability of quotas and time constraints each lecturer can distribute the material automatically quickly, and accurately and effective time and place, and easily precisely does not make students become bored and makes students easy to access when, where, and at a certain time, it depends on the activity of the learner at all times.

Online-learning offers flexibility. From interviews, flexibility becomes the main online-learning opportunity offered. The flexibility refers to the ease of access to which students can access anytime and from anywhere. Some of the students who have been interviewed included: Nurhidayati, Ahmad Fatoni, Sasmita, Marni, kilan and admitted that online-learning offers flexibility in terms of time and place. In interviews they stated:

One of the opportunities is flexibility where we can access online-learning from anywhere, anytime, and under any situation. We just need to have gadgets and an internet connection. Online-learning is not limited to space and time. So, more flexible (Nurhidayati). Online-learning opportunities are more flexible and efficient in terms of time and place, as can be done anytime and anywhere (Ahmad Fatoni). The onlinelearning opportunity is that we can learn from anywhere not just from the classroom. As long as we have connections, we can learn (Sasmita). Online-learning is more flexible and easy. We don't have to come to class. Also, we can do it everywhere (Marni). Onlinelearning opportunities are flexible and accessible. It can be done anytime and anywhere as long as there is internet access. It's flexible in time and place (Kilan).

The participants made several key points regarding flexibility in online learning. First, online learning is not limited to space and time. Second, by using online-learning, students can learn from any place, not just from the classroom. Lastly, to be able to access materials with online-learning, an internet connection is essential. Online learning provides flexibility in learning supported by (Smart, K. L., \& Cappel, 2006) which argues that online-learning brings flexibility and convenience because online-learning allows students to access lessons anytime and anywhere, and students can complete units of all teaching materials delivered by educators quickly. 
Challenges,

Online

learning,

EFL, Adult

learner

\section{Teaching EFL Online Learning Challenges}

Results of Observations, documentation, and interviews show that lecturers and students have challenges and opportunities concerning how to operate online classes. Challenges faced by lecturers and learners such as limitations in explaining learning 022 materials related to the variety of learning methods carried out. In the previous conventional class, lecturers had a creation, flexibility, and diversity of teaching methods that were filled with materials, characteristics of assignments, characteristics of learners, situations and learning environments, and so on. However, lecturers have limited ability to explain because learning is done online. It also challenges lecturers and students in carrying out learning activities. Activities are limited to sharing learning materials, videos, assignments, voice mail, and related information that has a limited interaction pattern, namely from lecturer to student and from student to the lecturer. Interaction patterns between students are quite limited. Group or pair work activities have not been seen in learning, so activities that require students to discuss and group are still limited. Studentcentered learning cannot be done because of all materials, activities, questions, tasks, and information centered or sourced from lecturers.

Lecturers and students are also constrained by learning time which makes the development, explanation, strengthening, enrichment of learning materials, and clarification of materials difficult to do. For example, some students who do not understand the material in a predetermined learning period should ask the lecturer directly through the lecturer's personal WA. Lecturers cannot explore widely both in terms of techniques, strategies, and methods to give lectures online due to limited space and time. time constraints and methods or techniques in providing satisfactory explanations to students are more than difficult enough to provide online. The same thing happens to students. Providing feedback, from all responses there are signal constraints as obstacles and cannot be connected properly through the internet network. These limitations can be caused by residences and domiciles that are far from the internet network that is sufficient to be connected.

The limited financial and economic condition of families for disadvantaged and remote villages as a concern: especially during the Covid-19 pandemic brought 22 heads of family to have difficulty in providing internet quota for their children during online classes that have a very high level of need during online. Thankfully, when the data 
collection of this research ended, the government had provided free quota assistance for Challenges, students since the 3rd week and 4th of September 2020. However, it is not having vouchers and internet pulses but another challenge that arises is some areas where students live difficult to reach signals. The village that the internet network is very weak inactivate.

Some students report that they are experiencing disruption or difficulty signaling in the area where they live.

We are well aware of that, that the importance of technology and information as a development that is highly superior to online learning. The solution is very appropriate for the government, lecturers, and other educators. So that lecturers give thought to create a WA group for each class collectively. This is a special concern for educators and lecturers to be used as challenges to be free and can be a common idea in finding the right solution. Challenges for lecturers and students of UIN Mataram Indonesia to adapt to English learning as an EFL foreign language online.

Challenges of lecturers and students in the utilization of information technology in Online Learning. The use of smartphones and laptops in online learning can increase what will happen to learners (Anggrawan, 2019). That poly over-use of information and communication technology in online learning software, among others, means not tied to space and when (Pangondian, R. A., Santosa, P. I., \& Nugroho, 2019). Research has been conducted that examines the use of gadgets such as smartphones and laptops in learning. The ability of smartphones and laptops to access the internet helps students to follow online learning (Kay, R. H., \& Lauricella, 2011) ; (Gikas, J., \& Grant, 2013);(Chan, N. N., Walker, C., \& Gleaves, 2015); (Gökçearslan, Ş., Mumcu, F. K., Haşlaman, T., \& Çevik, n.d.). The use of online learning using zoom cloud meeting has the advantage of being able to interact exclusively between students and lecturers as well as teaching materials but has the disadvantage of being extravagant and less effective when more than 20 learners (Naserly, 2020).

Furthermore, the challenge of online learning is the availability of internet services. Some students access the internet using cellular services, and some use WiFi services. When the online learning policy was implemented at the University of Jambi, students returned home. They have difficulty cellular frequency when in their respective regions if there is a frequency produced that is very weak. Online learning has weaknesses when internet services are weak, and the instruction of lecturers who are poorly 
Challenges,

Online

learning,

EFL, Adult

learner

understood by the student (Astuti, P., \& Febrian, 2019). in (Sadikin, A., \& Hamidah, 2020b).

\section{Positive and Negative Impacts of Online Learning for Adult Learners}

Students state that the opportunity to access subject matter from any location at any time is the most positive aspect of online learning. Besides, lecturers can integrate application or web-based resources into learning materials without difficulty. This gives students individual and unique learning opportunities. However, some students argues that online learning has positive and negative impacts:

Table 3. The impact of Online Learning

\begin{tabular}{|c|l|}
\hline No & \multicolumn{1}{|c|}{ Those are online learning has positive and negative impacts } \\
\hline A & Online learning has positive impacts \\
\hline 1 & $\begin{array}{l}\text { The positive impact is that we can maximize the use of technology that has } \\
\text { developed today. }\end{array}$ \\
\hline 2 & $\begin{array}{l}\text { We can get the material easily and in accordance with the way we learn can } \\
\text { be in accordance with our desires for example when lying down, while } \\
\text { eating, or when chatting with other people. }\end{array}$ \\
\hline 3 & $\begin{array}{l}\text { We can also be free to study without the standard time that is usually } \\
\text { determined for each course on campus. }\end{array}$ \\
\hline B & Online learning has negative impacts \\
\hline 1 & $\begin{array}{l}\text { The negative impact online learning process is only happen in one } \\
\text { direction, making it difficult for students to consult with material that is felt } \\
\text { to need a deeper explanation or understanding. }\end{array}$ \\
\hline 2 & $\begin{array}{l}\text { Teaching and learning activities which should be replaced by online } \\
\text { lectures but only replaced by the accumulation of assignments that make } \\
\text { me dizzy. }\end{array}$ \\
\hline 3 & $\begin{array}{l}\text { Online learning are seen in the technicality of the actual use of it. These } \\
\text { impacts include how technology is not always efficient, it is harder for } \\
\text { students to grasp concepts being taught, online learning can cause social } \\
\text { isolation, and can cause students to not develop needed communication } \\
\text { skills. }\end{array}$ \\
\hline
\end{tabular}

Researchers concluded that challenges of lecturers and in online learning at UIN Mataram, in the teaching of language lecturers and students with the challenge of learning from the house and work from house for these lecturers, is a new history in learning this century, teaching materials can be controlled with technology media in tying materials to students. The main challenge is that lecturers receive English language material every time they lecture online, lecturers cannot face-to-face and cannot control students well in online learning activities, but the positive impact for lecturers are very large because each 
material presented is widely accessible to students and can ask freely through what's-app messages and online media with Zoom meeting.

Students can surf with technology to explore the ability of ideas and idea them in presenting the language of oral communication through social media in the form of what-app and video presented in each learning activity in the lecture and student learning results can be presented at the end of the lecture through the language of communication by making video- vlog and handed over to the lecturer the results of learning after the study. Students' Ability to speak English is also presented in the form of writing as by the topic of learning the time of the perfect year.

Online learning using online applications with the advantages possessed by students can foster independence in learning English, this is in line with the opinion expressed by Oknisih, N., \& Suyoto (2019). Furthermore, Kuo, Y. C., Walker, A. E., Schroder, K. E. E., \& Belland, n.d. states that student-centered online learning can provide responsibility and independence in independent learning. Online learning is also emphasized in this statement that online learning requires students to prepare for learning, evaluate, organize, and at the same time maintain motivation in learning (Sadikin, A., \& Hamidah, 2020).

The researchers included documentation of action, showing the activity of students distribution of material before online lectures the mechanism of speech learning by providing mechanisms of communication and English both individually and in groups by doing according to the instructions by writing the script in advance and communicating directly with the interlocutor accompanied by topics and texts that have been presented by each student.

\section{CONCLUSION}

Based on the findings and discussion, the researcher concludes that the challenges of teaching online are real. The students or teachers dealing the challenges, difficult to get good internet access, and even several students do not have a smartphone. Besides, since the pandemic situation the normal class at school cannot be used, so conduct online classes is a better way. However, the normal activity in the classroom is giving another atmosphere to the teaching-learning processes. Furthermore, the results also show that the problems caused by internet access and the teaching ways between online and normal classes are the main problem. The lecturer and students surely want to
Challenges,

Online

learning,

EFL, Adult

learner 
Challenges,

Online

learning,

EFL, Adult

learner

back to the normal class, although the internet easier the teaching-learning process, however teaching online may not effectively be applied if the teacher and students do not ready yet. The solution are providing internet data packages for the students and the teacher, additional time for the students to send their assignment.

From the above exposure, it can be concluded that since the outbreak of the

Covid-19 pandemic, all learning processes in different parts of the world have changed from face-to-face mode to online mode. The application of this online mode always provides challenges and convenience to all parties involved in it. Challenges arise not only in developing countries, but also in developed countries such as Germany, South Korea, and China. The challenges are related to class management and technical learning system which includes the preparation, implementation, and evaluation of online learning that still requires contributing advice from all stakeholders in the world of education including observers of the world of education and education policymakers.

Finally, even though online-learning has many potentials and advantages until the challenges of e-learning are considered, the full potential and advantages cannot be fully obtained by the student. The implication for the Institute, online -learning can be an alternative method to prevent the spread of covid-19 and learning continues to run normally and lancer. Online learning for lecturers and students provides free movement of space and time to provide materials and students can access freely and at any time both materials and tasks submitted. For other researchers, it is expected to be able to find simple methods and easier for future learners.

\section{REFERENCES}

Allo, M. D. G. (2020). Is online learning good in the midst of Covid-19 Pandemic? The case of EFL learners. Jurnal Sinestesia, Jurnal Sinestesia, 10((1)), 1-10.

Anggrawan, A. (2019). Analisis Deskriptif Hasil Belajar Pembelajaran Tatap Muka dan Pembelajaran Online Menurut Gaya Belajar Mahasiswa. MATRIK: Jurnal Manajemen, Teknik Informatika Dan Rekayasa Komputer, 18(2), 339-346. https://doi.org/https://doi.org/10.30812/matrik.v18i2.411

Astuti, P., \& Febrian, F. (2019). Blended Learning Syarah: Bagaimana Penerapan dan Persepsi Mahasiswa. Jurnal Gantang, 4((2), ), 111-119. https://doi.org/https://doi.org/10.31629/jg.v4i2.1560

Carrillo, C., \& Flores, M. A. (2020). . COVID-19 and teacher education: a literature review of online teaching and learning practices. .1821184. European Journal of Teacher

Education, $43((4)$,$) ,$

466-487. 
https://doi.org/https://doi.org/10.1080/02619768.2020

Challenges,

Online

Chan, N. N., Walker, C., \& Gleaves, A. (2015). An exploration of students' lived experiences of using smartphones in diverse learning contexts using a hermeneutic phenomenological approach. Computers \& Education, 82, 96-106.

Creswell, J. W., \& Creswell, J. david. (2018). Research Design Qualitative, Quantitative, and Mixed Methods Approaches (Fifth Edit). Sage Publications, Inc

Dabbagh, N. and R. B. B. (2005). . Online Learning, Concepts, Strategies And Application. : Pearson.

Gikas, J., \& Grant, M. M. (2013). . Mobile computing devices in higher education: Student perspectives on learning with cellphones, smartphones \& social media. , 19, 18-26. The Internet and Higher Education, 19, 18-26.

Gökçearslan, Ş., Mumcu, F. K., Haşlaman, T., \& Çevik, Y. D. (n.d.). Modeling smartphone addiction: The role of smartphone usage, self-regulation, general selfefficacy and cyberloafing in university students. Computers in Human Behavior, 63, 639-649.

Handarini, O. I., \& Wulandari, S. S. (2020). Pembelajaran Daring Sebagai Upaya Study From Home (SFH) Selama Pandemi Covid 19. (JPAP),. Jurnal Pendidikan Administrasi Perkantoran, 8((3),), 496-503.

Huang, R., Tlili, A., Chang, T. W., Zhang, X., Nascimbeni, F., \& Burgos, D. (2020). Disrupted classes,undisrupted learning during COVID-19 outbreak in China: application of open educational practices andresources. Smart Learning Environments, 7(1). https://doi.org/10.1186/s40561-020-00125-8

Inchiparamban, S., \& Pingle, S. (2016). Massive open online courses (MOOCs): Why do we need them? (ED590312). ERIC. http://files.eric.ed.gov/fulltext/ED590312.pdf

Kay, R. H., \& Lauricella, S. (2011). Exploring the Benefits and Challenges of Using Laptop Computers in Higher Education Classrooms: A Formative Analysis. Canadian Journal of Learning and Technology /La Revue Canadienne de $l$ 'apprentissage et de La Technologie. https://doi.org/. https://doi.org/10.21432/t2s598

Kuo, Y. C., Walker, A. E., Schroder, K. E. E., \& Belland, B. R. (n.d.). Interaction, Internet self-efficacy, and self-regulated learning as predictors of student satisfaction in online education courses. Internet and Higher Education., 20, 35-50. https://doi.org/https://doi.org/10.1016/jiheduc.2013.10.001

Naserly, M. K. (2020). IMPLEMENTASI ZOOM, GOOGLE CLASSROOM, DAN WHATSAPP GROUP DALAM MENDUKUNG PEMBELAJARAN DARING (ONLINE) PADA MATA KULIAH BAHASA INGGRIS LANJUT (Studi Kasus Pada 2 Kelas Semester 2, Jurusan Administrasi Bisnis, Fakultas Ekonomi dan Bisnis, Universitas Bina Sa. Aksara Public, 4(2), 155-165.

Oknisih, N., \& Suyoto, S. (2019). PENGGUNAAN APLEN (APLIKASI ONLINE) SEBAGAI UPAYA KEMANDIRIAN BELAJAR SISWA. In SEMINAR NASIONAL PENDIDIKAN DASAR, 1(1).

Pangondian, R. A., Santosa, P. I., \& Nugroho, E. (2019). Faktor-Faktor Yang Mempengaruhi Kesuksesan Pembelajaran Daring Dalam Revolusi Industri 4.0. (Vol. 1, No. 1). In Seminar Nasional Teknologi Komputer \& Sains (SAINTEKS).

Sadikin, A., \& Hamidah, A. . (2020b). Pembelajaran Daring di Tengah Wabah Covid19:(Online Learning in the Middle of the Covid-19 Pandemic). Biodik,. Biodik, 6((2), ), 214-224.

Simamora, R. M. (2020). . The Challenges of Online Learning during the COVID-19 
Challenges,

Online learning, EFL, Adult learner
Pandemic: An Essay Analysis of Performing Arts Education Students. , https://doi.org/10.46627/silet.v1i2.38. Studies in Learning and Teaching, 1(2), 86103.

Smart, K. L., \& Cappel, J. J. (2006). Students' perceptions of online learning: A comparative study. (C. Cope, Ed.) , 5,. Journal of Information Technology Education, 5(1), 201-219.

028 Suni Astini, N. K. (2020). Tantangan Dan Peluang Pemanfaatan Teknologi Informasi Dalam Pembelajaran Online Masa Covid-19. ,. Cetta: Jurnal Ilmu Pendidikan, 3(2), 241-255. https://doi.org/https://doi.org/10.37329/cetta.v3i2.452

Sepulveda-Escobar, P., \& Morrison, A. (2020). Online teaching placement during the COVID-19 pandemic in Chile: challenges and opportunities. European Journal of Teacher Education, 43(4), 587-607. 